\title{
Hubungan Antara Perilaku Bullying dengan Efikasi Diri Pada Remaja
}

\author{
Jenita Laurensia Saranga', Siprianus Abdu, Agustina Lorensia Marampa, Asnia Mangalla \\ Program Studi Ilmu Keperawatan, Sekolah Tinggi Ilmu Kesehatan Stella Maris Makassar
}

\section{Info Artikel}

\section{Riwayat Artikel:}

Received : 25 Oktober 2021

Revised : 29 November 2021

Accepted : 02 Desember 2021

\section{Kata Kunci:}

Perilaku Bullying

Efikasi Diri

Remaja

\begin{abstract}
ABSTRAK
Bullying sudah menjadi masalah global yang kerap dijumpai dan dihadapi banyak orang khususnya remaja, baik sebagai pelaku bullying maupun korban dari perilaku bullying. Bullying adalah suatu bentuk perilaku agresif yang terjadi berulang kali dengan cara menyakiti fisik maupun mental yang dilakukan oleh anak ataupun sekelompok anak terhadap anak yang lain. Kejadian bullying yang dihadapi remaja dapat berdampak pada efikasi diri remaja. Efikasi diri merupakan kemampuan seseorang atau individu dalam menyelesaikan tugas atau masalah sehingga dapat mencapai tujuan dalam mengatasi hambatan yang dialami. Remaja dengan efikasi diri yang tinggi memiliki kepercayaan dan kemampuan untuk menyelesaikan masalah dengan kontrol kinerja yang efektif. Penelitian ini bertujuan untuk menganalisa hubungan antara perilaku bullying dengan efikasi diri remaja di SMA Negeri 1 Tana Toraja. Jenis penelitian ini adalah observasional analitik dengan pendekatan cross sectional study. Teknik sampling yang digunakan adalah proportionate stratified random sampling dengan jumlah sampel 200 responden. Instrumen yang digunakan adalah kuesioner. Dari hasil uji statistik Chi-Square diperoleh nilai $\rho=0,000$ dengan tingkat kemaknaan $\alpha=$ 0,05 . Hal ini menunjukkan $\rho<\alpha$, artinya ada hubungan yang signifikan antara perilaku bullying dengan efikasi diri remaja di SMA Negeri 1 Tana Toraja. Dengan demikian semakin tinggi perilaku bullying maka semakin rendah efikasi diri remaja ataupun sebaliknya.
\end{abstract}

This is an open access article under the $\underline{C C B Y-S A}$ license.

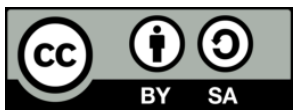

\section{Corresponding Author:}

Jenita Laurensia Saranga',

Prodi Ilmu Keperawatan, STIK Stella Maris Makassar,

Jl.Maipa No.19, Makassar, Indonesia.

Email: sarangajenita@gmail.com

\section{PENDAHULUAN}

Tindakan bullying sudah menjadi masalah global yang kerap dijumpai dan dihadapi banyak orang khususnya remaja termasuk remaja di sekolah menengah pertama (SMP) dan di sekolah menengah atas (SMA). Bullying yakni perilaku yang agresif dan terjadi berulang kali dengan cara menyakiti fisik ataupun mental yang dilakukan oleh seorang maupun sekelompok anak kepada anak yang lain (Sufriani \& Sari, 2017). Sari \& Azwar (2017) mengatakan bullying bukan hanya berupa tindakan kekerasaan namun bisa berupa intimidasi, memaksa, memaki, menggosip, memberi julukan dan lainnya. Bullying sendiri memiliki beberapa model diantaranya: bullying secara verbal, bullying nonverbal, bullying secara relasional atau psikologi dan cyber bullying. Dampak yang ditimbulkan ketika seseorang atau lebih melakukan perilaku bullying yaitu cenderung berperilaku agresif lalu terlibat di sebuah kelompok dan aktivitas kenakalan yang lain. Sebaliknya dampak yang dapat dirasakan oleh korban bullying yakni memiliki masalah emosi atau perasaan, harga diri rendah, tertekan, suka menyendiri dan merasa tidak aman (Pusdatin Kemenkes RI, 2018). Dampak yang dialami oleh anak yang terkena bullying dapat diminimalkan dengan harapan anak memiliki resiliensi. Resiliensi adalah kemampuan yang dimiliki anak untuk dapat mempertahankan kembali kesehatan mental meski sedang mengalami kesulitan (Herrman et al., 2011). Sumber resiliensi yang harus dimiliki pada anak yang mengalami perlakuan bullying diantaranya adalah dukungan sosial, adanya kekuatan dalam diri setiap anak serta terdapatnya kemampuan interpersonal, dan terdapat beberapa faktor dalam pembentukan resiliensi salah satunya yakni efikasi diri. 
Efikasi diri ialah perasaan atau keyakinan dari seseorang atau individu terhadap kemampuannya dalam mengerjakan suatu tugas, mengatur serta melaksanakan suatu tindakan. Efikasi diri tinggi maupun rendah berkombinasi terhadap lingkungan yang responsif dan tidak responsif. Ketika efikasi diri yang rendah dan berkombinasi dengan lingkungan yang responsif maka seseorang akan mengalami stres ataupun depresi disebabkan karena individu melihat bahwa orang lain dapat menyelesaikan persoalan dengan baik, kemudian saat efikasi diri seseorang rendah berkombinasi dengan lingkungan yang tidak responsif hingga orang-orang akan merasa segan, apatis dan tidak berdaya (Feist \& Feist, 2014). Efikasi seseorang dalam perihal menangani kejadian bullying yang terjadi adalah kemampuan diri sendiri dalam merespon dan menangani kejadian bullying yang terbagi lagi dalam beberapa aspek-aspek efikasi diantaranya; efikasi perilaku, efikasi kognitif, serta efikasi emosi. Jika seseorang atau remaja memiliki efikasi diri yang tinggi maka individu tersebut akan memiliki motivasi yang baik untuk berubah atau dengan mudah mengatasi masalah yang dihadapi, sebaliknya jika seseorang atau remaja memiliki efikasi diri yang rendah hingga orang atau remaja tersebut susah mempunyai motivasi yang positif dan kurang memiliki keyakinan untuk berubah (Rustika, 2012).

Di dunia terdapat $54 \%$ kejadian bullying ataupun kekerasan fisik yang terjadi, kemudian terdapat $64 \%$ kejadian bullying untuk di wilayah Asia, dan berdasarkan laporan UNICEF tahun 2015 mengungkapkan kekerasan yang terjadi pada anak ataupun remaja di indonesia semakin meningkat yakni $40 \%$ kejadian diserang secara fisik, 26\% kejadian mendapatkan hukuman fisik baik dari orang tua maupun pengasuh yang berada di rumah, dan 50\% kejadian bully di sekolah (Pusdatin Kemenkes RI, 2018). Kasus bullying yang terjadi di Sulawesi Selatan terdapat 1,584 kasus, terkhusus di daerah Tana Toraja terdapat 70 kasus (Kepolisian Indonesia, 2019). Jika kejadian bullying tidak dapat ditangani dengan baik maka angka kejadian bullying akan terus meningkat, ketika seorang remaja dihadapkan pada kasus bullying diharapkan efikasi remaja tersebut dapat mengatasi masalah yang dihadapi oleh remaja tersebut, jika tidak dapat diatasi dengan baik, maka dapat berdampak kepada mental remaja, individu tersebut dapat menjadi stres dan apabila koping stres tidak baik maka kejadian yang paling di takutkan terjadi adalah bunuh diri, oleh sebab itu efikasi diri memiliki hubungan penting untuk mengatasi kejadian bullying yang kerap dihadapi oleh sebagian besar remaja.

Menurut Yusuf \& Fahrudin (2012), perilaku bully merupakan satu dari banyak masalah tingkah laku dan disiplin di kalangan murid sekolah dewasa ini, perilaku bully secara langsung atau tidak langsung merupakan sebagian dari tingkah laku agresif. Kemudian menurut Anggraini, et al., (2020) mengungkapkan bahwa korban bullying yang mempunyai self-efficacy dalam mengatasi dampak negatif perilaku bullying mampu menggunakan strategi dan mendesain serangkaian kegiatan untuk merubah keadaan. Hal ini diperkuat oleh Amawidyati \& Muhammad (2017), mengungkapkan bahwa tentang program psikoedukasi bullying efektif untuk meningkatkan efikasi diri setiap individu.

Berdasarkan beberapa study penelitian di atas dan fenomena yang penulis temukan di sekitar lingkungan masyarakat maupun sekolah pada saat melakukan survey awal, ada beberapa anak atau remaja yang berkata kasar terhadap anak yang lain, dan adanya efikasi diri seseorang yang masih rendah ketika menghadapi bullying. Efikasi diri dari seorang anak atau remaja yang tidak efektif yang dapat berdampak buruk kepada kesehatan mental anak atau remaja inilah yang menjadi alasan bagi peneliti untuk melakukan penelitian ini.

\section{METODE PENELITIAN}

Jenis penelitian yang digunakan adalah observasional analitik dengan pendekatan cross sectional study yaitu jenis penelitian melihat hubungan variabel independen dengan variabel dependen, dimana pengukuran dilakukan secara bersamaan yang bertujuan untuk menganalisis hubungan antara perilaku bullying dengan efikasi diri remaja. Penelitian ini dilakukan di SMA Negeri 1 Tana Toraja pada 02 Februari - 19 Februari 2021. Populasi pada penelitian ini adalah semua remaja atau siswa(i) SMA Negeri 1 Tana Toraja sebanyak 1100 siswa/siswi. Pengambilan sampel dalam penelitian ini menggunakan teknik pengambilan sampel probability sampling dengan pendekatan proportionate stratified random sampling dengan ukuran sampel 200 responden.

Instrumen yang digunakan dalam penelitian ini berupa kuesioner. Kuesioner ini telah dilakukan uji validitas dengan hasil rhitung $>$ rtabel dan nilai sig $<0,05$. Variabel independen perilaku bullying dengan jumlah 30 item pertanyaan, dan variabel dependen efikasi diri sebanyak 13 item pertanyaan. Dalam hal pengumpulan data penelitian juga mengedepankan etika penelitian seperti informed Consent, anonymity, confidentiality. Jenis data yang dikumpulkan adalah data primer dan data sekunder.

Pengolahan data yang dilakukan dengan menggunakan program SPSS versi 24 yang diawali dengan editing, coding, processing dan cleaning. Selanjutnya data dianalisis secara univariate dan bivariate. Analisis univariate digunakan untuk mengetahui distribusi frekuensi dan persentase dari setiap variabel yang diteliti, sedangkan analisis bivariate digunakan untuk melihat hubungan variabel independen (perilaku bullying) dan 
variabel dependen (efikasi diri). Analisis bivariate menggunakan uji Chi - Square dibaca di Continuity Correction dengan tingkat kemaknaan $\alpha=0,05$ dengan interpretasi (1) jika nilai $\rho<\alpha$, artinya ada hubungan antara perilaku bullying dengan efikasi diri pada remaja (2) jika nilai $\rho \geq \alpha$, artinya tidak ada hubungan perilaku bullying dengan efikasi diri pada remaja.

\section{HASIL}

\subsection{Karakteristik Demografi Responden}

Tabel 1. Distribusi Frekuensi Responden Berdasarkan Kelompok Usia, Jenis Kelamin dan Kelas di SMA Negeri 1 Tana Toraja 2021

\begin{tabular}{ccccc}
\hline $\begin{array}{c}\text { Kategori } \\
\text { Usia }\end{array}$ & Frekuensi & Persentase (\%) & n & \% \\
\hline 14 & 2 & 1,0 & & \\
15 & 39 & 19,5 & & \\
16 & 62 & 31,0 & 200 & 100,0 \\
17 & 66 & 33,0 & & \\
18 & 31 & 15,5 & & \\
\hline Jenis Kelamin & & & & \multirow{2}{*}{100,0} \\
\hline Laki-laki & 74 & 37,0 & \\
Perempuan & 126 & 63,0 & & 100,0 \\
\hline Kelas & 66 & 33,0 & & \\
\hline X & 66 & 33,5 & & \\
XI & 67 & 33,5 & & \\
XII & 67 & & & \\
\hline
\end{tabular}

Tabel 1 di atas menunjukkan distribusi frekuensi berdasarkan usia, diperoleh data bahwa dari 200 responden jumlah responden terbanyak berada pada usia 17 tahun yaitu sebanyak $66(33,0 \%)$ responden, sedangkan jumlah responden terkecil berada pada usia 14 tahun yaitu $2(1,0 \%)$ responden. Kemudian distribusi frekuensi berdasarkan jenis kelamin, diperoleh data bahwa dari 200 responden jumlah responden terbanyak berada pada kelompok yang berjenis kelamin perempuan sebanyak 126 (63,0\%) responden, sedangkan jumlah responden terkecil berada pada kelompok yang berjenis kelamin laki-laki sebanyak 74 $(37,0 \%)$ responden. Sedangkan distribusi frekuensi berdasarkan tingkat kelas, diperoleh data dari 200 responden jumlah responden terbanyak berada pada tingkat kelas XI dan kelas XII masing-masing sebanyak $67(33,5 \%)$ responden, sedangkan jumlah responden terkecil berada pada tingkat kelas X sebanyak 66 $(33,0 \%)$ responden.

\subsection{Analisis Univariat}

Tabel 2. Distribusi Frekuensi Responden Berdasarkan Perilaku Bullying pada Siswa/Siswi di SMA Negeri 1 Tana Toraja 2021

\begin{tabular}{ccc}
\hline Perilaku Bullying & Frekuensi & Persentase (\%) \\
\hline Rendah & 88 & 44,0 \\
Tinggi & 112 & 56,0 \\
\hline Total & 200 & 100,0 \\
\hline
\end{tabular}

Dari tabel 2 di atas menunjukkan bahwa dari 200 responden diperoleh data perilaku bullying paling banyak adalah kategori tinggi yaitu sebanyak $112(56,0 \%)$ responden, Sedangkan perilaku bullying yang paling rendah adalah kategori rendah yaitu sebanyak 88 (44,0\%) responden. 
Jurnal Keperawatan Florence Nightingale, Vol. 4, No. 2, Desember 2021: pp. 83-88

Tabel 3. Distribusi Frekuensi Responden Berdasarkan Jenis-jenis Bullying pada Siswa/Siswi di SMA Negeri 1 Tana Toraja

\begin{tabular}{|c|c|c|c|c|}
\hline Perilaku Bullying & Frekuensi & Persentase $(\%)$ & $\mathbf{n}$ & $\%$ \\
\hline \multicolumn{5}{|l|}{ Bullying Verbal } \\
\hline Tinggi & 93 & 46,5 & \multirow{2}{*}{200} & \multirow{2}{*}{100,0} \\
\hline Rendah & 107 & 53,5 & & \\
\hline \multicolumn{5}{|l|}{ Bullying Fisik } \\
\hline Tinggi & 53 & 26,0 & \multirow{2}{*}{200} & \multirow{2}{*}{100,0} \\
\hline Rendah & 148 & 74,0 & & \\
\hline \multicolumn{5}{|l|}{ Bullying Psikologis } \\
\hline Tinggi & 64 & 32,0 & \multirow{2}{*}{200} & \multirow{2}{*}{100,0} \\
\hline Rendah & 136 & 68,0 & & \\
\hline \multicolumn{5}{|l|}{ Bullying Cyber } \\
\hline Tinggi & 60 & 30,0 & \multirow{2}{*}{200} & \multirow{2}{*}{100,0} \\
\hline Rendah & 140 & 70,0 & & \\
\hline
\end{tabular}

Dari tabel 3 di atas menunjukkan bahwa dari 4 jenis perilaku bullying didapatkan hasil tertinggi pada perilaku bullying verbal sebanyak 93 (46,5\%) responden dan hasil terendah pada jenis perilaku bullying fisik sebanyak 53 (26\%) responden yang mengalami perilaku bullying dari 200 responden.

Tabel 4. Distribusi Frekuensi Responden Perilaku Bullying Berdasarkan Kelas/Tingkatan pada Siswa/Siswi SMA Negeri 1 Tana Toraja

\begin{tabular}{|c|c|c|c|c|c|c|c|c|}
\hline \multirow{3}{*}{$\begin{array}{l}\text { Perilaku } \\
\text { Bullying }\end{array}$} & \multicolumn{6}{|c|}{ Kelas } & \multicolumn{2}{|c|}{ Total } \\
\hline & \multicolumn{2}{|c|}{$\mathbf{X}$} & \multicolumn{2}{|c|}{ XI } & \multicolumn{2}{|c|}{ XII } & \multirow{2}{*}{$\mathrm{n}$} & \multirow{2}{*}{$\%$} \\
\hline & $\mathrm{n}$ & $\%$ & $\mathrm{n}$ & $\%$ & $\mathrm{n}$ & $\%$ & & \\
\hline Tinggi & 21 & 10,5 & 43 & 21,5 & 48 & 24,0 & \multirow{2}{*}{200} & \multirow{2}{*}{100,0} \\
\hline Rendah & 45 & 22,5 & 24 & 12,0 & 19 & 9,5 & & \\
\hline
\end{tabular}

Dari tabel 4 di atas menunjukkan bahwa dari 200 responden diperoleh data perilaku bullying tinggi dengan hasil tertinggi terdapat pada tingkat XII sebanyak $48(24 \%)$ responden dan hasil terendah pada tingkat X sebanyak $21(10,5 \%)$ responden.

Tabel 5. Distribusi Frekuensi Responden Berdasarkan Efikasi Diri Pada Siswa/Siswi SMA Negeri 1 Tana Toraja 2021

\begin{tabular}{ccc}
\hline Efikasi Diri & Frekuensi & Persentase (\%) \\
\hline Tinggi & 94 & 47,0 \\
Rendah & 106 & 53,0 \\
\hline Total & 200 & 100,0 \\
\hline
\end{tabular}

Dari tabel 5 di atas menunjukkan bahwa dari 200 responden diperoleh data responden yang memiliki efikasi diri rendah sebanyak $106(53,0 \%)$ responden, sedangkan responden yang memiliki efikasi diri tinggi sebanyak $94(47 \%)$ responden.

Tabel 6. Distribusi Frekuensi Efikasi Diri Responden Berdasarkan Kelas/Tingkatan pada Siswa/Siswi SMA Negeri 1 Tana Toraja

\begin{tabular}{|c|c|c|c|c|c|c|c|c|}
\hline \multirow{3}{*}{ Efikasi } & \multicolumn{6}{|c|}{ Kelas } & \multicolumn{2}{|c|}{ Total } \\
\hline & \multicolumn{2}{|c|}{$\mathbf{X}$} & \multicolumn{2}{|c|}{ XI } & \multicolumn{2}{|c|}{ XII } & \multirow[b]{2}{*}{$\mathrm{n}$} & \multirow{2}{*}{$\%$} \\
\hline & $\mathrm{n}$ & $\%$ & $\mathrm{n}$ & $\%$ & $\mathrm{n}$ & $\%$ & & \\
\hline Tinggi & 30 & 15,0 & 32 & 16,5 & 32 & 16 & 94 & 47,5 \\
\hline Rendah & 36 & 18,0 & 35 & 17,5 & 35 & 17 & 106 & 52,5 \\
\hline Total & 66 & 33 & 67 & 34 & 67 & 33 & 200 & 100 \\
\hline
\end{tabular}


Dari tabel 6 di atas menunjukkan bahwa dari 200 responden diperoleh data efikasi diri rendah paling banyak pada tingkat X yaitu sebanyak $36(18 \%)$ responden dan efikasi diri tinggi paling banyak pada tingkat XI dan XII yaitu masing- masing sebanyak $32(16,5 \%)$ responden.

\subsection{Analisis Bivariat}

Tabel 7. Hubungan Antara Perilaku Bullying Dengan Efikasi Diri Pada Remaja Di SMA Negeri 1 Tana Toraja 2021

\begin{tabular}{|c|c|c|c|c|c|c|c|}
\hline \multirow{3}{*}{ Perilaku Bullying } & \multicolumn{6}{|c|}{ Efikasi Diri } & \multirow{3}{*}{$\rho$} \\
\hline & \multicolumn{2}{|c|}{ Tinggi } & \multicolumn{2}{|c|}{ Rendah } & \multicolumn{2}{|c|}{ Total } & \\
\hline & $\mathrm{n}$ & $\%$ & $n$ & $\%$ & $n$ & $\%$ & \\
\hline Rendah & 55 & 27,5 & 33 & 16,5 & 88 & 44,0 & \multirow{2}{*}{0,000} \\
\hline Tinggi & 39 & 19,5 & 73 & 36,5 & 112 & 56,0 & \\
\hline Jumlah & 94 & 47 & 106 & 53 & 200 & 100 & \\
\hline
\end{tabular}

Dari tabel 7 diatas menunjukkan tabulasi silang dari hasil uji statistic. Hasil uji statistik disimpulkan bahwa ada hubungan antara perilaku bullying dengan efikasi diri remaja pada siswa SMA Negeri 1 Tana Toraja. Hasil ini didukung oleh sel yang menjelaskan bahwa perilaku bullying rendah dan efikasi diri tinggi sebanyak $55(27,5 \%)$ responden, sedangkan perilaku bullying tinggi dan efikasi rendah sebanyak $73(36,5 \%)$ responden.

Hasil lain dalam penelitian ini menunjukkan adanya perilaku bullying rendah dan efikasi diri rendah sebanyak $33(16,5 \%)$ responden dan perilaku bullying tinggi dan efikasi diri tinggi sebanyak 39 (19,5\%) responden.

\section{DISKUSI}

Temuan penelitian ini menunjukkan signifikansi antara perilaku bullying dengan efikasi diri pada remaja. Hasil ini didukung oleh temuan yang menunjukkan bahwa responden yang menerima perlakuan bullying rendah dan efikasi diri tinggi sebanyak 55 (27,5\%) responden, serta responden yang menerima perlakuan bullying tinggi dan efikasi rendah sebanyak 73 (36,5\%) responden. Hal ini diperkuat oleh penelitian dari Anggraini, Azizah Heru et al., (2020) ketika seorang remaja mengalami perilaku bullying akan mendapatkan dampak negatif dimana remaja tersebut akan mengalami gangguan psikologi, tertekan, merasa rendah diri dan tidak berharga serta hilangnya atau rendahnya kepercayaan terhadap diri sendiri dalam menangani masalah atau persoalan yang sedang dialaminya hal ini yang membuat sehingga efikasi dari remaja dapat menurun.

Menurut Rigby (2014), bullying menjadi masalah yang sering terjadi di lingkungan sekolah yang membuat korban memiliki harga diri yang rendah, ide untuk bunuh diri, depresi stress, kesepian, kecemasan, dan gangguan tidur. Menurut Rustika (2012), efikasi diri adalah salah satu faktor yang terpenting yang berkontribusi terhadap perubahan perilaku, pengalaman yang lebih positif yang diperoleh seseorang akan memberikan kesadaran untuk mengambil keputusan. Ada beberapa faktor yang dapat mempengaruhi terjadinya bullying yaitu faktor teman sebaya dan faktor media (Bulu, Maemunah, \& Sulasmini, 2019).

Hasil penelitian yang didapatkan sejalan dengan beberapa penelitian sebelumnya antara lain penelitian yang dilakukan oleh Haraldstad K, Kvarme L, Christophersen K, \& Helseth S (2019), yang bertujuan untuk mengetahui peran efikasi diri umum atau General Self Efication (GSE) dan bullying dalam kaitannya dengan kualitas hidup yang berhubungan dengan kesehatan. Pada penelitian lain yang dilakukan oleh Thornberg \& Jungert (2015), yang bertujuan untuk mengetahui bagaimana kepekaan dasar moral dalam bullying dan efikasi diri terkait dengan perilaku yang berbeda dalam bullying, efikasi diri yang tinggi akan memberi motivasi dan melibatkan remaja untuk menghindari perilaku bullying dan bahkan dapat membantu korban bullying.

Hasil lain dalam penelitian ini menunjukkan adanya responden yang dengan perilaku bullying yang tinggi dan efikasi diri yang tinggi sebanyak 39 (19,5\%) responden. Hal ini didukung oleh penelitian Tumon (2014), efikasi yang tinggi dimiliki remaja yang mengalami perilaku bullying yang artinya remaja tersebut dapat mengatasi perilaku bullying yang dihadapinya, karena adanya kemampuan adaptasi dari dalam diri seseorang yang sehat terhadap lingkungannya, serta dukungan sosial atau adanya suatu perhatian dan bantuan yang dirasakan oleh seseorang dari orang-orang terdekat atau keluarga serta mekanisme koping yang baik akan mempengaruhi bagaimana remaja tersebut dapat mengatasi masalah yang sedang dihadapi. Implikasi 
pada temuan ini adalah mengenai efikasi diri yang baik dapat mempengaruhi seseorang dalam menghadapi perilaku bullying.

\section{KESIMPULAN}

Berdasarkan hasil penelitian dapat disimpulkan bahwa Ada hubungan yang signifikan antara perilaku bullying dengan efikasi diri pada remaja di SMA Negeri 1 Tana Toraja. Perilaku bullying terhadap siswa di SMA Negeri 1 Tana Toraja berada pada kategori tinggi sedangkan efikasi berada pada kategori rendah.

\section{REFERENSI}

Amawidyati, S. A. G., \& Muhammad, A. H. (2017). Program Psikoeduasi Bullying Untuk Meningkatkan Efikasi Diri Guru Dalam Menangani Bullying Di Sekolah Dasar. Intuisi : Jurnal Psikologi Ilmiah, 9(3), 258-266.

Anggraini, D. S., Azizah Heru, M. J., Jatimi, A., Munir, Z., \& Rahman, H. F. (2020). Efektivitas Self Efficacy Mengahadapi Bullying Di Sekolah. Quality: Jurnal Kesehatan, 14(2), $74-84$. https://doi.org/10.36082/qjk.v14i2.108

Bulu, Y., Maemunah, N., \& Sulasmini. (2019). Faktor-faktor Yang Mempengaruhi Perilaku Bullying Pada Remaja Awal. Nursing News, 4(1), 54-66.

Feist, J., \& Feist, G. J. (2014). Teori Kepribadian (7th ed.). Jakarta: Salemba Humanika.

Haraldstad K, Kvarme L, Christophersen K, \& Helseth S. (2019). Associations Between Self-efficacy, Bullying And Health-related Quality of Life in a School Sample of Adolescents: a Cross-Sectional Study. BMC Public Health, 19(1), 1-9.

Herrman, H., Stewart, D. E., Diaz-Granados, N., Berger, E. L., Jackson, B., \& Yuen, T. (2011). What is Resilience? Canadian Journal of Psychiatry, 56(5), 258-265. https://doi.org/10.1177/070674371105600504

Kepolisian. (2019). Rencana Kerja Polres Tana Toraja (Vol. 8). https://doi.org/10.22201/fq.18708404e.2004.3.66178

Pusdatin Kemenkes RI. (2018). Data KPAI Tentang Kekerasan Pada Anak.pdf.

Rigby, K. (2014). Self-Efficacy Differences Between Perpetrators and Victims. Journal of Chemical Information and Modeling, 53(9), 1689-1699.

Rustika, I. M. (2012). Efikasi Diri: Tinjauan Teori Albert Bandura. Buletin Psikologi, 20(1-2), 18-25. https://doi.org/10.22146/bpsi.11945

Sari, Y. P., \& Azwar, W. (2017). Fenomena Bullying Siswa: Studi Tentang Motif Perilaku Bullying Siswa di SMP Negeri 01 Painan, Sumatera Barat. Ijtimaiyya: Jurnal Pengembangan Masyarakat Islam, 10(2), 333-367. https://doi.org/10.24042/ijpmi.v10i2.2366

Sufriani, \& Sari, E. P. (2017). Faktor Yang Mempengaruhi Bullying Pada Anak Usia Sekolah Di Sekolah Dasar Kecamatan Syiah Kuala Banda Aceh. Faktor Yang Mempengaruhi Bullying Pada Anak Usia Sekolah Di Sekolah Dasar Kecamatan Syiah Kuala Banda Aceh, 8(3).

Thornberg, R., \& Jungert, T. (2015). Bystander Behavior in Bullying Situations: Basic Moral Sensivity, Moral Disengagement and Defender Self-efficacy. Adolescence, 130(4), A79-A80.

Tumon, M. B. A. (2014). Studi Deskriptif Perilaku Bullying pada Remaja Matraisa Bara Asie Tumon. 3(1), 1-17.

Yusuf, H., \& Fahrudin, A. (2012). Perilaku Bullying: Asesmen Multidimensi Dan Intervensi Sosial. Jurnal Psikologi, 11(2), 10. https://doi.org/10.14710/jpu.11.2.10 